\title{
PENGARUH FORMULASI TEPUNG PANGAN LOKAL TERHADAP PENILAIAN ORGANOLEPTIK DAN PROKSIMAT PRODUK MUFFIN: STUDI KEPUSTAKAAN
}

\author{
[Effect of Formulations of Local Flour on Muffin Product Organoleptic and Proximate: A Review] \\ Nella Veby Agustin ${ }^{1^{*}}$, Sri Wahyuni ${ }^{1}$, RH. Fitri Faradilla ${ }^{1}$ \\ 1 Jurusan IImu dan Teknologi Pangan, Fakultas Pertanian, Universitas Halu Oleo, Kendari \\ *Email: vebyagustinnella@gmail.com (Telp: +628187116217)
}

Diterima tanggal 14 Juni 2019

Disetujui tanggal 19 Juni 2019

\begin{abstract}
This review aimed to determine the effect of the treatment of various types of local flour formulations on the organoleptic characteristics of the muffin products. In addition, this review also aimed to determine the nutritional value of muffin products from local food. The formulation process of various types of flour is carried out to improve the organoleptic characteristics of the muffins produced and to determine the level of consumer acceptance of the product using local flour. The review results show that the proximate value of each formulation of the type of local flour produces different proximate values. Organoleptic characteristics of muffin using local food flour show that the taste and texture assessment had different results for each flour formulation.
\end{abstract}

Keywords: muffin, Local flour

\section{ABSTRAK}

Review ini bertujuan untuk mengetahui pengaruh perlakuan formulasi berbagai jenis tepung pangan lokal terhadap karakteristik organoleptik produk muffin yang dihasilkan. Selain itu, review ini juga bertujuan untuk mengetahui nilai gizi produk muffin dari pangan lokal. Proses formulasi berbagai jenis tepung dilakukan untuk memperbaiki karakteristik organoleptik muffin yang dihasilkan serta untuk mengetahui tingkat penerimaan konsumen terhadap produkmuffin menggunakan tepung pagan lokal. Hasil review menunjukkan bahwa nilai proksimat setiap formulasi dari jenis tepung pangan lokal menghasilkan nilai proksimat yang berbeda. Karakteristik organoleptik muffint erhadap penggunaan tepung pangan lokal terhadap rasa dan tekstur setiap formulasi tepung akan menghasilkan hasil produk yang berbeda.

Kata kunci: Muffin, tepung pangan lokal.

\section{PENDAHULUAN}

Muffin merupakan produk bakery yang berasal dari Inggris dan saat ini telah banyak dikenal oleh masyarakat Indonesia. Berdasarkan data tahun 2014 data statistik komsumsi produk roti manis di Indonesia termasuk muffin yakni sebanyak $25.792 \mathrm{Kg}$ (BPS, 2015). Muffin adalah sejenis cake yang dibuat dalam ukuran personal, teksturnya padat, agak menggumpal di bagian isinya, dan bentuknya mirip dengan cupcake. Muffin 
dikenal sebagai roti berbentuk cangkir yang dihidangkan dalam kondisi panas dan dapat dikonsumsi sebagai makanan berat ataupun makanan ringan (Smith dan Hui 2004). Muffin yang saat ini umumnya dikembangkan menggunakan tepung terigu sebagai bahan utama dalam pembuatan muffin sehingga menyebabkan indonesia harus mengimpror tepung terigu.

Berdasarkan Badan Pusat Statistik (2016), impor gandum di Indonesia pada tahun 2014 mencapai 7,39 juta ton, sedangkan pada tahun 2015 angka tersebut meningkat menjadi 7,49 juta ton. Departemen Pertanian Amerika Serikat (USDA) memperkirakan impor gandum di Indonesia pada tahun 2016 akan mencapai angka 8,10 juta ton. Kebutuhan yang besar terhadap tepung terigu sebagai bahan pembuatan produk muffin menjadi masalah bagi indonesia saat ini (Setyawan, 2007).

Usaha untuk mengurangi konsumsi tepung terigu digalakkan disamping mencari alternatif pengganti dari bahan baku lain, juga dengan mengusahakan tepung lain sebagai tepung campuran, yaitu beberapa jenis tepung dari bahan lain seperti sumber karbohidrat (serelia dan umbi-umbian) (Hidayat, 2000). Tujuan pembuatan muffin dengan menggunakan beberapa kombinasi tepung pangan lokal antara lain untuk mendapatkan karakteristik bahan yang sesuai untuk produk olahan yang diinginkan atau untuk mendapatkan sifat fungsional tertentu dan tepung pangan lokal mempunyai kelebihan antara lain memiliki nilai gizi yang lebih tinggi dibandingkan dengan hanya satu jenis tepung saja, serta kualitas fisik dan organoleptik yang lebih baik (Tajudin, 2014). Oleh karena itu tepung pangan lokal dapat digunakan dalam pembuatan muffin sebagai alternatif bagi konsumen yang ketergantungan terhadap bahan pangan berbasis tepung terigu.

\section{Nilai proksimat Muffin}

Hasil analisis nilai proksimat muffin dari berbagi tepung komposit dapat dilihat pada Tabel 1.

Tabel 1. Nilai gizi muffin dari berbagi tepung komposit

\begin{tabular}{lccc}
\hline \multicolumn{1}{c}{ Fomulasi } & $\begin{array}{c}\text { Kadar Kabohidrat } \\
(\%)\end{array}$ & $\begin{array}{c}\text { Kadar protein } \\
(\%)\end{array}$ & $\begin{array}{c}\text { Kadar lemak } \\
(\%)\end{array}$ \\
\hline $\begin{array}{l}\text { Tepung ubi jalar kuning }(50 \%) \text { : Tepung terigu } \\
(50 \%)^{a}\end{array}$ & 41,6 & 7,91 & 11,30 \\
$\begin{array}{l}\text { Tepung ubi jalar ungu (75\%) : Tepung terigu } \\
(25 \%)^{b}\end{array}$ & 31,11 & 7,54 & 23,64 \\
Tepung sorgum (40\%) : Tepung terigu (60\%) & 61,94 & 7,90 & 28,57 \\
tepung ubi jalar (10\%) :Tepung terigu(4\%) : & 69,82 & 5,89 & 22,46 \\
tepung jagung (86\%) d & & & \\
\hline Sumber: (a). Hardiyanti, 2018 (b). Nurdjanah et al., 2017. (c). Hanani, 2015, (d). Stefani, 2012.
\end{tabular}




\section{Kadar Karbohidrat}

Karbohidrat disebut juga zat pati atau zat tepung atau zat gula yang tersusun dari unsur Karbon (C), Hidrogen $(\mathrm{H})$, dan Oksigen $(\mathrm{O})$. Di dalam tubuh karbohidrat akan dibakar untuk menghasilkan tenaga atau panas. Satu gram karbohidrat menghasilkan empat kalori (Winarno, 2004). Berdasarkan pada tabel 1 kandungan kadar karbohidrat muffin yang tertinggi yaitu pada formulasi tepung ubi jalar : tepung jagung : tepung terigu 69,82\%, dan terendah pada formulasi Tepung ubi jalar ungu :Tepung terigu 31,11\%. Berdasarkan komposisi zat gizi ubi jalar per 100 gram (Direktorat Gizi Departemen Republik Indonesia 1991) bahwa karbohidrat muffin ubi jalar kuning lebih tinggi 32,3\% dibandingkan dengan ubi jalar ungu hanya 29,7\% akibat adanya komponen bahan tambahan pangan yang meningkatkan kadar karbohidrat yakni: margarin, telur, susu dan gula serta adanya kombinasi tepung jagung dan tepung terigu yang dapat meningkatkan kadar karbohidrat. Penurunan kadar karbohidrat pada muffin pada formulasi tersebut disebabkan disebabkan oleh jenis ubi jalar yang berbeda dan penanganan panen. Widjanarko (2008) menyatakan bahwa penggunaan suhu yang tinggi dapat merusak molekul-molekul pada karbohidrat sehingga nilai gizinya menurun, selain itu pengolahan yang melibatkan pemanasan yang tinggi pada karbohidrat terutama gula akan mengalami karamelisasi (pencoklatan non enzimatis) yang juga bisa menyebabkan kerusakan yang ekstensif (Afrianti, 2013).

\section{b. Kadar Protein}

Asam amino merupakan konstituen penting dalam pangan yang menyediakan bahan baku untuk biosintesis protein. Selain itu, asam amino juga berkonstribusi terhadap flavor dan prekursor senyawa aroma dan warna selama reaksi enzimatik. pengolahan dan penyimpanan makanan, protein juga berkontribusi terhadap sifat fisik makanan karena kemampuannya untuk stabilisasi, busa, emulsi, dan stabilitas gel (Belitz dan Grosch, 2009). Berdasarkan Tabel 1 kadar protein muffin pada formulasi tepung ubi jalar kuning : tepung terigu memiliki tingkat kadar protein yang tinggi 7,91\% sedangkan yang terendah pada formulasi tepung ubi jalar : tepung jagung : tepung terigu (5,89\%). Proporsi peggunaan tepung pada pembuatan muffin sangat mempengaruhi kadar protein pada muffin yakni semakin tinggi penggunaan tepung untuk pembuatan muffin maka kadar proteinnya semkin meningkat begitupun sebaliknya jika semakin rendah proporsi penggunaan tepung maka kadar proteinnya menurun.

\section{Kadar Lemak}

Lemak adalah senyawa ester dari gliserol dan asam lemak. Lemak merupakan sumber energi bagi tubuh yang memberikan nilai energi lebih besar daripada karbohidrat dan protein yaitu $9 \mathrm{kkal} / \mathrm{g}$ (Kurtzweil, 2006). Berdasarkan data pada Tabel 1, kadar lemak muffin yang tertinggi terdapat pada formulasi tepung sorgum :tepung terigu $28,57 \%$ sedangkan yang terendah pada formulasi tepung ubi jalar ungu : tepung terigu 
$11,30 \%$. Berdasarakan standar mutu roti manis SNI (01-3840-1995) pada kadar lemak bahwa dari semua formulasi melebihi dar standar 3\%, hal ini disebabkan karena adanya perbedaan komposisi bahan yang digunakan sehingga kadarnya jauh melebihi SNI. Selain itu, muffin dibuat dengan sebagian besar komposisi bahan adalah margarin yaitu sebanyak 50 - 100 gram untuk pembuatan satu kali adonan.

\section{Karakteristik Organoleptik Muffin}

Karakteristik organoleptik muffin dilakukan untuk mengetahui tingkat penerimaan konsumen terhadap produk yang dihasikan dari berbagai jenis tepung pangan lokal meliputi rasa dan tekstur. Berikut karakteristik muffin dari berbagai jenis tepung pangan lokal dapat dilihat tabel.

Tabel 2. Karakteristik Organoleptik muffin dari berbagai jenis tepung pangan lokal.

\begin{tabular}{lcc}
\multicolumn{1}{c}{ Fomulasi } & Rasa & Tekstur \\
\hline Tepung ubi jalar kuning $(50 \%)$ : Tepung terigu (50\%) a & 4,8 (Biasa) & 3,7 (Biasa) \\
Tepung ubi jalar ungu $(75 \%)$ : Tepung terigu $(25 \%)^{\text {b }}$ & 4,00 (Suka) & 3,50 (lembut) \\
Tepung sorgum (40\%) : Tepung terigu $(60 \%)^{c}$ & - & - \\
tepung ubi jalar (10\%) :Tepung terigu(4\%) : tepung & - & \\
jagung $(86 \%)^{\text {d }}$ & &
\end{tabular}

Sumber: (a). Hardiyanti, 2018 (b). Nurdjanah et al., 2017. (c). Hanani, 2015, (d). Stefani, 2012.

\section{Rasa}

Rasa merupakan faktor yang sangat penting dalam menentukan keputusan konsumen dalam menerima atau menolak suatu produk makanan adalah parameter rasa. Rasa dimulai melalui tanggapan rangsangan kimiawi oleh indera pencicip (lidah), sampai akhirnya terjadi keseluruhan interaksi antara sifat-sifat aroma, rasa, dan tekstur sebagai keseluruhan rasa makanan. Agar suatu senyawa dapat dikenali rasanya, senyawa tersebut harus larut dalam air liur sehingga dapat mengadakan hubungan mikrovillus dan impuls yang terbentuk dikirim melalui syaraf ke pusat syaraf. Dengan rasa tersebut, konsumen dapat memutuskan menerima atau menolak produk tersebut. Ada 4 jenis rasa dasar yang dikenali yaitu: manis, asin, asam, dan pahit. Sedangkan rasa lainnya merupakan perpaduan dari rasa dasar (Soekarto, 1985). Rasa merupakan faktor yang sangat menentukan keputusan akhir konsumen untuk menerima atau menolak suatu produk dan faktor lain yang diduga mempengaruhi rasa adalah proses pemanggangan dimana pemanggangan bertujuan mendapatkan cita rasa yang menarik dan flavour yang khas (Herni et al., 2018). Meskipun warna dan aroma suatu produk baik tetapi rasanya tidak enak maka makanan tersebut akan ditolak. Rasa dapat ditentukan dengan cecapan dan rangsangan mulut. Tekstur dan konsistensi suatu bahan akan mempengaruhi cita rasa yang ditimbulkan oleh bahan tersebut (Winarno, 2004). 


\section{Tekstur}

Tekstur adalah manifestasi sensori dan fungsional dari sifat struktural, mekanikal, dan permukaan dari produk pangan yang dapat dideteksi melalui indera penglihatan, pendengaran, perasa, dan kinestetik. Tekstur merupakan salah satu karakteristik produk pangan yang penting dalam mempengaruhi penerimaan konsumen (Albanjar et al., 2014). Konsistensi atau tekstur makanan juga merupakan komponen yang turut menentukan cita rasa makanan karena sensitifitas indera cita rasa dipengaruhi oleh aktivitas air banyak hal yang mempengaruhi tekstur pada bahan pangan antara lain rasio kandungan protein, lemak, jenis protein, suhu pengolahan, dan kadar air. Tekstur merupakan salah satu faktor yang mempengaruhi pilihan konsumen terhadap suatu produk pangan. Tekstur juga merupakan sekelompok sifat fisik yang ditimbulkan oleh elemen struktural bahan pangan yang dapat dirasakan (Purnomo,1995). Umumnya konsumen menyukai makanan yang mempunyai tekstur yang tinggi. Alasannya karena konsumen menyukai bahan pangan yang agak basah serta mudah dikunyah. Jadi kebasahan, empuk, mudah dikunyah, merupakan faktor tekstur yang dikehendaki (Purnomo 1995).

\section{KESIMPULAN}

Perbedaan hasil analisis proksimat produk muffin dari berbagai jenis tepung pangan lokal dikarenakan perbedaan formulasi dan campuran bahan lainnya. Selain itu proporsi penggunaan tepung terhadap formulasi mempengaruhi nilai proksimat. Penilaian karakteristik organoleptik muffin dimaksudkan sebagai cara untuk meningkatkan penerimaan konsumen terhadap produk yang dihasilkan dari berbagai jenis tepung pangan lokal. Pengaruh penggunaan tepung pangan lokal tehadap pembuatan produk muffin sangat mempengaruhi respon penerimaan konsumen terhadap karakteristik organoleptik muffin .

\section{DAFTAR PUSTAKA}

Albanjar, F. V, E. Nurali, L. Lalujan dan T. Langi. 2014. Evaluasi Kualitas Sensoris Muffin Berbahan Baku Pisang Goroho (Musa acuminate sp.). Pontianak Nutrition Journal (PNJ). 5. (2). 1-6

Afrianti, L.H. 2013. Teknologi Pengawetan Pangan. Alfabeta. Bandung

BPS. 2015. Konsumsi Pangan Pada Produk Roti Manis Di Indonesia. Badan Pusat Statistik.

Belitz, H.D. and W.Grosch. 2009. Food Chemistry. Second Edition. Springer .Berlin.

Hanani, N,S. 2015. Eksperimen Pembuatan Muffin Bahan Dasar Tepung Terigu Substitusi Tepung Ganyong. Skripsi. Semarang. Fakultas Teknik Universitas Negeri Semarang. 
Hardiyanti., M.S.T. 2018. Analisis Kandungan Zat Gizi Muffin Ubi Jalar Kuning (Ipomoea Batatas L.) Sebagai Alternatif Perbaikan Gizi Masyarakat. Public health science journal. 10 (1):108-119

Herni. S., Tamrin. Dan Asyik. N. 2018. Penilaian Organoleptik Serta Proksimat Biskuit Tinggi Serat Berbasis Tepung Kaopi Fermentasi Dan Ampas Kelapa. J. Sains Dan Teknologi Pangan. 3.(3) :1379-1392.

Kurtzweil, P. 2006. Daily Valves Encourage Healthy Diet. http://www.fda.gov/fdac/spectual/foodlabel/dvs.htm. Diakses tanggal 15 Juni 2019. Surakarta. ISBN 978-92-5-107554-8.

Nurdjanah, S., Yuliana. N., Zuidar. S. A., dan Naim. E. I . 2017. Kharakteristik Muffin Dari Tepung Ubi jalar Ungu Kaya Pati Resisten. Majalah Teknologi Agro Industri (Tegi). 9. (2). 1-10

Purnomo, H. 1995. Aktivitas Air dan Peranannya dalam Pengawetan Pangan. Penerbit Universitas Indonesia. Jakarta.

Setyanti, 2015. Kualitas Muffin Dengan Kombinasi Tepung Sorgum (Sorghum Bicolor) Dan Tepung Terigu (Triticum Aestivum). Skripsi. Yogyakarta Fakultas Teknobiologi Universitas Atmajaya. Yogyakarta.

Soekarto.S,T. 1985. Penelitian organoleptik. Bharta karya Aksara. Jakarta.

Smith, J,S dan Hui YH. 2004. Food Processing: Principles and Applications. New York: Wiley-Blackwell.

Standar Nasional Indonesia (SNI). 1995. SNI Roti No. 01-3840-1995. Badan Standar Nasional.Jakarta.

Stefani,H. 2012. Optimasi Formula Dan Proses Pembuatan Muffin Berbasis Substitusi Tepung Komposit Jagung Dan Ubi Jalar Kuning. Jurnal Teknologi dan Industri Pangan. 23(2) : 1-8

Winarno, F.G., 2004. Kimia Pangan dan Gizi. PT. Gramedia Pustaka Utama. Jakarta.

Widjanarko, S. 2008. Efek Pengolahan terhadap Komposisi Kimia \& Fisik Ubi Jalar Ungu dan Kuning. http://simonbwidjanarko.wordpress.com (diakses 15 Juni 2019 ). 